Artikel Konseptual

\title{
KEARIFAN LOKAL MASYARAKAT MALANG DALAM PENDIDIKAN PENGUATAN KARAKATER DI SMAN 1 SUMBERPUCUNG
}

\author{
Melaningrum Andarwati \\ melaningruma@gmail.com
}

SMAN 1 Sumberpucung

\begin{abstract}
The fading of local wisdom values and the loss of solidarity can lead to the conflict. It is characterized by such qualities as disrespecting the rights of others, disturbing public order, feeling most correct, and ignoring the opinions of others. This will threaten Indonesia's Bhineka Tunggal Ika. To deal with this problem one of the things that can be done is exploring the noble values of the nation that are stored in local wisdom and implementing it on learning activities at school. SMA Negeri 1 Sumberpucung is one of the institutions that implements the local wisdom of the people of Malang in character education through extracurricular and intrecolic activities. The values of local wisdom of the people excavated are honesty, independence, determination of heart, togetherness, tolerance, social sensitivity, lugas, equality, simplicity, peace, progressive and appreciating the pluralist of culture. Students are taught to have a local wisdom spirit through the creativity of art, social activities, and customs that can be enjoyed by the local community. This implementation has a positive impact on the students of SMAN 1 Sumberpucung.
\end{abstract}

Key words: local wisdom, character education, student

\section{PENDAHULUAN}

Akhir-akhir ini sedang marak isu tentang suku ras dan agama serta masuknya paham-paham radikalisme ke Indonesia yang mengancam tegaknya keutuhan NKRI. Hal ini menyebabkan rusaknya identitas bangsa Indoneisa sebagai akibat dari maraknya konflik horizontal atas nama aga dan hilangnya rasa toleransi. Munculnya ketidakmauan unutk hidup bersama dalam masyarakat yang majemuk berdampak pada munculnya tindakan tidak toleran dalam bentuk permusuhan, sikap diskriminatif dan tindakan kekerasan kepada pihak yang berbeda orentasi hidup berbangsa dan bernegara dengan dasar utama kultural dalam berperikemanusiaan, berkeadilan sosial dalam hubungan sesama, berketahanan dalam mensyukuri dan memuliakan hidup, berasas bersama menghormati azas mufakat, berdaulatnya rakyat, demokratis menjadi bangsa Indonesia kerap dicederai oleh kekosongan teladan perilaku (Sutrisno, 2011). Persilangan nilai budaya Indonesia dan budaya global harus dikelola dengan baik agar tidak menjadi ancaman bagi kelangsungan hidup berbangsa dan bernegara (Komensos, 2017). 
Untuk menghadapi permasalahan bangsa di atas, penguatan karakter harus dikembalikan pada jati diri bangsa Indonesia. Karakter yang kuat hanya bisa dibangun jika manusia mau dan mampu melihat dirinya sendiri, karena manusia seringkali bermasalah dengan hidupnya ketika ia tidak mampu berdamai dengan dirinya sendiri (Triguna, 2011). Permasalahan tentang karakter dan kebhinekaan yang sedang dihadapi bangsa memang harus segera dicari solusi. Untuk menyelesaikan permasalahan bangsa Indonesia dapat dilakukan dengan membangun manusia Indonesia kembali pada diri sendiri melalui kearifan lokal Nusantara sebagai jati diri bangsa.

Penguatan pendidikan karakter dapat dilakukan dengan menjadikan kearifan lokal sebagai landasan pendidikan. Pendidikan yang dimaksud dikembangkan dalam kerangka pengayaan nilai-nilai budaya. Hal ini diharapkan mampu menghadirkan situasi dimana siswa lebih dekat dengan lingkungannya sehingga tumbuh perasaan memiliki dan melestarikan nilai-nilai lokal tersebut (Nadlir,2014).

Pendidikan berbasis kearifan lokal dapat digunakan sebagai media untuk melestarikan potensi daerah (Afiqoh, Atmaja, Saraswati 2018). SMA Negeri 1 Sumberpucung telah memasukan kearifan lokal dalam rangka pendidikan penguatan karakter baik melalui kegiatan intrakurikuler maupun ekstrakurikuler. Tulisan ini akan mengkaji tentang, kearifan lokal dalam pendidikan karakter, kearifan lokal masyarakat Malang dalam pendidikan penguatan karakter, dan aplikasi kearifan lokal masyarakat Malang dalam pendidikkan penguatan karakter di SMAN 1 Sumberpucung. Tujuan tulisan ini untuk menginspirasi agar sekolah-sekolah yang ada di Malang raya sebagai tempat pendidikan penguatan karakter mengajarkan nilai -nilai budaya pada siswa dengan mengaplikasikan kearifan lokal masyarakat Malang yang penuh kebajikan, kearifan, sportivitas, integritas, pluralitas menjadi landasan dasar pendidikan penguatan karakter sehari-hari .

\section{KEARIFAN LOKAL DALAM PENDIDIKAN KARAKTER}

Salah satu sisi dari era globalisasi adalah munculnya tuntutan untuk kembali pada budaya bangsa masing-masing agar dalam peleburan tanpa batas yang diakibatkan oleh kemajuan teknologi informasi tidak berdampak pada hilangnya jatidiri bangsa. Oleh karena itu dewasa ini banyak kajian mengenai kearifan lokal. Ridwan (2007) menyatakan bahwa kearifan lokal merupakan usaha manusia dengan memanfaatkan akal budinya untuk bertindak dan bersikap terhadap objek atau peristiwa dalam ruang tertentu. Hal ini berarti bahwa kearifan lokal dipahami sebagai kemampuan individu dalam menilai objek atau peristiwa tertentu secara arif dan bijaksana. Kearifan lokal sering disebut juga sebagai local wisdom. 
Kearifan lokal dalam UUD 1945 Pasal 28 I ayat (3) menyatakan bahwa identitas budaya dan hak masyarakat tradisional dihormati selaras dengan perkembangan jaman dan peradaban. (UUD1945; 2013) berdasarkan pasal 28 I ayat (3) di atas dapat diartikan bahwa identitas budaya masyarakat tradisional dalam hal ini kearifan lokal yang ada pada masyarakat dilindungi oleh undang-undang. Kearifan lokal masyarakat Indonesia harus tetap dilestarikan oleh generasi muda. Kearifan lokal mengandung pengertian sebagi nilai-nilai luhur yang berlaku dalam tata kehidupan masyarakat untuk melindungi tata lingkungan hidup untuk kelestarian kehidupan masyarakat yang sudah tertata baik (Unayah \& Sabarisma, 2017).

Penggalian terhadap nilai-nilai luhur budaya bangsa penting untuk dilakukan sebagai upaya untuk mengkritisi keniscayaan perubahan budaya yang muncul dari adanya globalisasi. Untuk melakukan hal tersebut perlu ruang kajian tersendiri baik dalam kehidupan secara umum melalui kegiatan diskusi informal maupun melalui pendidikan formal di sekolah. Ciri khas kedaerahan yang berupa kearifan lokal mencakup beberapa aspek yaitu sosial ekonomi, budaya, ekologi, agama dan komunikasi (Ahmad 2012).

Setiap daerah setidaknya memiliki keunggulan kearifan lokal baik berupa materi maupun non-materi. Keunggulan berupa materi dapat berbentuk sumber daya alam dan hasil bumi. Sedangkan keunggulan non-materi berupa kesenian, tadiri, budaya dll. Keunggulan tersebut terintegrasi dalam kehidupan sehari-hari dan tidak dapat dipisahkan dari masyarakat. Namun ketika hal tersebut ditinggalkan dan tidak diwariskan kepada generasi selanjutnya maka secara perlahan-lahan akan hilang.

Dalam rangka menghindari hilangnya kearifan lokal yang merupakan kekayaan nasional maka hal tersebut perlu diimplementasikan dalam pendidikan karakter di sekolah. Tujuan utama penerapan pendidikan karakter berbasis kearifan lokal adalah mengembangkan potensi peserta didik agar menjadi manusia yang religius penuh keimanan dan ketawaan kepada Tuhan Yang Maha Esa, memiliki akhlak terpuji, sehat, cakap, kreatif, mandiri, memiliki tanggungjawab dan bersikap demokratis agar mampu mengembalikan jatidiri bangsa Indonesia berdasar Pancasila (Ridwan 2017).

Pancasila sebagai dasar negara dan ideologi bangsa Indonesia merupakan intisari unsur kearifan lokal yang ada di daerah di seluruh Indonesia. Para pendiri bangsa Indonesia menelaah dengan teliti dan berdiskusi secara serius sehingga lahirnya ideologi Pancasila. Ki Hajar Dewantara dalam bukunya Soekarno Filsafat Pancasila menyatakan bahwa "Pancasila menjelaskan serta menegaskan corak warna atau watak rakyat Indonesia sebagai bangsa yang beradab, bangsa yang berkebudayaan, bangsa yang menginsafi keluhuran, keharmonisan hidup manusia yang sanggup beradaptasi dengan kehidupan kebangsaan dengan dasar perikemanusiaan universal yang meliputi seluruh 
alam kemanusiaan yang seluas-luasnya. Pancasila berkuasa menanamkan kreatifitas serta menjadi ilham dalam pembangunan masyarakat dan negara (Dewantara, 2017).

Pendidikan adalah pengetahuan, ketrampilan dan kebiasaan sekelompok orang yang diturunkan dari generasi kegenerasi berikutnya, melalui, pengajaran, pelatihan, sedangkan karakter adalah unsur kepribadian yang ditinjau dari segi etis dan moral. Karakter mengacu pada serangkaian, sikap, prilaku, motivasi, dan keterampilan sebagai manifestasi nilai dan kapasitas moral manusia dalam menghadapi kesulitan dengan nilai-nilai khas di antaranya nilai kebaikan, mau berbuat baik dalam kehidupan nyata mengambarkan penguatan karakter (Sriwilujeng, 2017). Sebagai wujud gerakan revolusi mental di era pemerintahan Presiden Joko Widodo dilakukan melalui pendidikkan karakter. Pendidikan karakter menjadi jantung hati dan poros pendidikan nasional.

Berdasarkan hasil penelitiannya Sriwilujeng (2017) menyimpulkan bahwa lima pilar utama penguatan pendidikan karakter adalah 1) Religius, suatu nilai yang mengajarkan keimanan kepada Tuhan YME yang termanifestasi dalam perilaku sehari-hari dengan menjalankan perintah agama secara teguh, menghargai agama dan kepercayaan orang lain, serta memiliki kemauan untuk hidup secara damai dan rukun; 2) nilai nasionalis yang teruwjud dalam bentuk kesetiaan, kepedulian, dan penghargaan terhadap bahasa, lingkungan fisik, sosial, budaya, ekonomi, dan politik serta berkemauan untuk menempatkan kepentingan bersama diatas kepentingan pribadi; 3) nilai mandiri yang berarti dapat berdiri di kaki sendiri tanpa ketergantungan terhadap orang lain serta mampu memanfaatkan segala daya upaya baik pikiran maupun waktu untuk mewujudkan cita-cita; 4) nilai gotong royong yang terwujud dalam tindakan untuk mau bekerjasama dalam kebaikan, senang bergaul dengan lintas latar belakang, serta memberikan bantuan kepada pihak-pihak yang membutuhkan.

Sekolah ataupun lembaga pendidikan yang lain merupakan sarana pewarisan budaya baik berupa nilai maupun ilmu kepada generasi masa depan yaitu siswa. Pewarisan ini harus dilaksanakan dengan terencana agar mampu melahirkan generasi muda yang siap menghadapi berbagai tantangan jaman. Salah satu perencanaan tersebut adalah menyelenggarakan pendidikan berbasis karakter yang dikemas dalam kegiatan pembelajaran intrakurikuler, ekstrakurikuler, maupun dalam bentuk pembiasaan dalam kehidupan sehari-hari di sekolah. Hal ini dilakukan dengan tujuan agar nilai-nilai luhur bangsa dapat menjadi sikap batin dan landasan perilaku dalam kehidupan di masyarakat. Oleh karena itu, proses pembalajaran dengan berlandaskan pendidikan karakter budaya bangsa sangat penting dilakukan. 


\section{KEARIFAN LOKAL MASYARAKAT MALANG DALAM PENGUATAN PENDIDI- KAN KARAKTER}

Menurut Budiprabowo (2017) masyarakat Malang adalah wujud keragaman. Secara historis Malang merupakan wilayah yang menjadi tujuan para migran sejak masa pemerintah kolonial. Kehadiran perkebunan dan lembaga pendidikan merupakan salah satu faktor penarik pendatang baru di Malang. Keberagaman suku, etnis, agama, tradisi, dan latar belakang sosial yang berbeda memberikan warna baru dalam sejarah Malang.

Orang yang menetap di Malang berasal dari berbagai daerah di Indonesia. Mereka menemukan keindahan dan keuntungan di wilayah yang dikelilingi oleh pegunungan dan berada di kawasan dataran tinggi. Hal ini berlangsung sejak masa kerajaan Medang sampai kerajaan Majapahit. Malang adalah wilayah yang selalu menjadi tempat penting bagi segala kebutuhan kehidupan manusia untuk membangun peradabannya. Nilai-nilai Kearifan lokal masyarakat Malang yang harus dilestarikan di antaranya karakter sportif, lugas, jujur, memiliki semangat kesetaraan, kesederhanaan, semangat perdamaian, progresif dan menghargai pluralis.

Kearifan lokal Malang Raya memiliki karakter yang khas salah satunya adalah bahasa lugas dengan ciri khas dibalik atau dikenal dengan bahasa walikan. Walik memiliki arti dibalik, biasanya sebuah kata dibaca dari belakang. Beberapa contoh yang banyak ditemui penggunaannya adalah kata "iyo" dalam bahasa Jawa diganti menjadi "oyi” yang berarti "iya" atau kata "tidak" yang dicaba "kadit". Orang Malang senang dengan lugas mengatakan sesuatu di depan orang lain jika itu dianggap perlu, omongan yang lain dibelakang orang lain dianggap sudah tidak penting, kejujuran dianggap sebagai nilai terpenting dalam berkomunikasi dilingkungan masyarakat umum. Orang Malang tidak menyukai bahasa yang berlebihan, menggunjing, dan gosip. Tindakan seperti itu dikenal dengan istilah kacangan yang artinya tidak memiliki keberanian dan hal ini adalah julukan orang-orang yang tidak memiliki kedewasaan.

Masyarakat Malang merupakan orang-orang yang sangat sensitif dengan ketidak jujuran, orang yang berkelit dari laku jujur atau berlaku curang, disebut nggapleki. Artinya sekalipun masih kelihatan putih dari bersihnya singkong, orang sudah bisa mencium baunya dan melihat perubahan warna menjadi makin kabur dan gelap. Itulah nggapleki, ciri khas kepribadian dari kearifan lokal dimiliki masyarakat Malang adalah kesederhanaan, masyarakat Malang tidak menyukai sesuatu yang berlebihan selalu berusaha menyederhanakan yang rumit, dengan memperkaya maknanya sebagai proyek ke utamaan. 
Tradisi budaya yang dikembangkan di Malang semua disederhanakan misalnya wayang kulit pertunjukannya tidak harus menggunakan perangkat lengkap disederhanakan dengan kondisi lingkungan setempat, karya budaya memasuki Malang akan menemukan semangat penyederhanaan, ketoprak akan disesuaikan dengan bahasa yang ada di daerah tidak terikat dengan aturan-aturan baku. Seni jaranan (kuda lumping), ludruk, gamelan, dimanfaatkan untuk membangun inovasi baru yang lebih relevan kontekstual dengan situasi masyarakat dan situasi jaman.

Masyarakat Malang memiliki ciri khas semangat kesetaraan diantara sesama penghuni Malang. Manusia dilihat sebagai manusia yang memeiliki kesetaraan satu dengan yang lain tanpa ada strata satu dengan yang lain. Seseorang, semuanya setara dalam posisi apa pun dari segi jabatan, kekayaan, keturunan, pangkat tidak ada yang berbeda dalam tatanan masyarakat. Mengistimewakan orang-orang tertentu, karena jabatan, status sosial, dan asal keturunan dengan mengutamakan orang-orang tertentu adalah hal-hal yang sangat memuakkan dan kecenderungan terhadap memuliakan seseorang secara berlebihan, dicurigai sebagai kemunafikan atau istilah populernya dalam masyarakat Malang adalah ngathok; memposisikan diri di bawah dan siap menjadi wadah segala hal yang buruk dan menjijikkan "saja".

Semangat masyarakat Malang adalah toleran, dan suka berdamai, hal ini dapat diamati dari simbol-simbol bangunan yang ada di wilayah Malah misalnya, bangunan Masjid Agung berdampingan dengan gereja di alun-alun Kota Malang, Masjid Sabilillah berhadapan dengan gereja katolik St Albertus di JL. A. Yani Kota Malang, menunjukan semangat keetaraan dan toleransi dalam menghargai perbedaan. Budaya masyarakat Malang tidak suka usil artinya tidak senang melakukan hal-hal tidak perlu, untuk mengganggu kenyamanan dan ketenangan orang lain.

Semangat damai dengan semangatnya "Satu Jiwa" adalah rasa seperasaan dan kesatuan sebagai bagian dari satu masyarakat yang sama. Pada masa pemerintahan Belanda kota Malang adalah menjadi kota yang maju dalam pembangunan dan sistem sosial hal ini dapat diamati dari tata kota Malang yang rapi modern dengan pembagian komunitas masyarakat yang berbeda ras tetapi tetap satu, misalnya di kota Malang ada sebutan Embong Arab terletak di sekitar jalanYulius Usman, jalan.Piere Tendean sampai jalan Kyai $\mathrm{H}$. Wahid Hasyim, jalan Ade Irma Suryani yang dihuni oleh pedagang Arab sejak masa pemerintahan kolonial Belanda, sedangkan Pecinan pasar besar sekarang di huni oleh pedagang Cina terletak di jalan Sutan Syahrir,jalan Pasar Besar, jalan Sugiyopranoto, jalan Agus Salim sampai daerah Zainul Arifin yang terdapat Klenteng tempat ibadah umat agama Khonghucu, segi tata kota sudah menunjukan progres bertoleransi, kesatuan itu teruji. Tanpa mempersoalkan agama, etnis, asal daerah, semua orang yang tinggal di Ma- 
lang berusaha mempertahankan wilayahnya. Semangat "Satu Jiwa" saat ini menjadi semangat suporter Arema yang menjadi kebanggaan dalam menunjukkan identitas diri. Jiwa progresif Masyarakat Malang yang penuh kreativitas dalam segala bidang menjadi semangat untuk maju diberbagai bidang di antaranya. Pendidikan, budaya, kesenian, olahraga yang selalu menghasilkan orang-orang terbaik dan memberi kebanggaan masyarakat Malang.

Pluralisme merupakan ciri khas sikap dari masyarakat Malang sebagai bentuk manifestasi kearifan lokal. Kesadaran individu dalam memupuk kemauan untuk memberi keleluasaan bagi berkembangnya keberagaman merupakan modal penting bagi kemajuan masyarakat di era globalisasi. Ditinjau secara geografis penduduk Malang merupakan orang-orang gunung yang seringkali memiliki karakter tangguh, pekerja keras, saling membantu, dan menghormati kemerdekaan setiap individu dalam menentukan setiap pilihan hidup. Budiprabowo (2017) menganalogikan pluralisme orang Malang seperti air yang kita minum (berarti menjadi sebuah kebutuhan) dan seperti darah yang mengalir di tubuh kita (berarti sangat urgen dalam kehidupan).

Malang terkenal dengan makanan khasnya produksi dari masyarakat asli Malang yang diwariskan secara turun temurun berupa jajanan pasar yang berupa produk makanan umumnya di buat secara tradisional dan dipasarkan di lingkup yang sempit misalnya hanya di pasar dan wilayah sekitar masyarakat. Makanan khas Malang melambangkan pluralisme masyarakatnya yang terdiri dari berbagai suku, agama, ras yang bersatu menjadi komunitas masyarakat yang menjunjung tinggi persatuan dan kesatuan.

Jenis jajanan pasar yang sering dijual yaitu Gathot: jajanan pasar berbahan utama singkong yang diiris persegi panjang dan dijemur sampai berubah warna menjadi hitam kemudian dikukus dan disajikan dengan kelapa parut, Gethuk: merupakan kue yang dibuat dari ubi jalar atau singkong yang dikukus dan dihaluskan, biasanya kalau terbuat dari ubi jalar disajikan dengan diptong kotak-kotak kecil dan ditaburi kelapa parut sedangkan kalau terbuat dari singkong dipres kedalam mesin pencetak yang akhirnya berbentuk kumpulan silinder yang dikenal dengan gethuk lindri, Thiwul: berbahan dasar tepung gaplek (singkong) yang kemudian dikukus jika matang berwarna coklat gelap, Horog-Horog: berbahan dasar tepung beras dikukus disajikan dalam bentuk warna -warna cerah, Brubi: berbahan dasar tepung beras dan pisang kapok, Puli : berbahan dasar beras (nasi) yang dibentuk, dijemur, dan digoreng, Cenil : berbahan dasar tepung Tapioka (singkong) dan disajikan dalam warna cerah, Klepon : kue berwarna hijau dengan isian gula merah dan dibentuk bulat, ireng-ireng: berbahan dasar tepung beras, dengan pewarnaan yang menggunakan air rendaman batang padi yang dibakar, ljo-ijo : berbahan dasar tepung beras, dengan pewarnaan yang menggunakan air ekstrak daun pandan suji , sebagai modifikasi dari ireng-ireng, Bledhus berbahan dasar pipilan jagung yang sudah JPSI, Vol. 2, No., 2, 2019 
tua. Jenis jajanan pasar yang ada di wilayah Kabupaten Malang sebagai produk pembuatannya masih manual dengan berbahan dasar dari bahan-bahan alam.

Disamping makanan, bahasa dan etika sosial kearifan lokal Malang yang dapat diimplementasikasikan dalam pendidikan karakter di sekolah adalah seni budaya Malang terkenal dengan budaya, kerajinannya, keramik Dinoyo, Topeng Malangan di Pakisaji dan seni Tari di antaranya "Tari Topeng Malangan" dapat diartikan sebagai gerakan badan yang berirama dengan diiringi bunyi-bunyian dengan menggunakan penutup muka yang menyerupai muka orang, tari ini murni berasal dari Malang di Kedungmonggo sebagai sebuah dusun di kaki gunung Kawi yang merupakan salah satu kantong persebaran seni budaya tari topeng Malang. Kondisi daerah Malang secara eksternal juga didukung dengan polesan konstruksi budaya Hindu-Jawa lokasinya terletak di sekitar dusun Kedungmonggo akar sejarah kemunculan tari topeng Malangan.

\section{APLIKASI PEMBELAJARAN KEARIFAN LOKAL MASYARAKAT MALANG DALAM PENDIDIKAN KARAKTER DI SMAN 1 SUMBERPUCUNG}

Sekolah merupakan tempat penanaman nilai ataupun ilmu pada siswa, yang akan membentuk pribadi-pribadi unggul yang cerdas dan berkarakter. Sekolah berkarakter merupakan upaya sekolah untuk menanamkan nilai-nilai budaya karakter dalam diri setiap warga sekolah melalui berbagai kegiatan baik dalam proses pembelajaran intrakurikuler, ekstrakurikuler.

Dalam rangka membangkitkan semangat melestarikan kearifan lokal masyarakat Malang. SMAN 1 Sumberpucung memiliki komitmen untuk melestarikan kearifan lokal masyarakat melalui pendidikan karakter yang diintegrasikan dalam kegiatan ekstrakurikuler dan sebagian pembelajaran intrakulikuler. Nilai-nilai kearifan lokal masyarakat Malang yang dapat diterapkan dalam Pendidikan karakter di sekolah dalam rangka revolusi mental di antaranya, nilai kejujuran, kemandirian, keteguhan hati, kebersamaan, toleransi, dan kepekaan sosial. Aplikasi pembelajaran kearifan lokal masyarakat Malang yang memiliki karakter lugas, jujur, memiliki semangat kesetaraan, kesederhanaan, semangat perdamaian, progresif dan menghargai pluralis melalui kebudayaan untuk menumbuhkan rasa solidaritas, memiliki kreativitas dalam karya seni, olah raga dan adat istiadat.

Selain melalui seni budaya dan olah raga penamaman kearifan lokal Masyarakat Malang yang berjiwa sportif jujur diterapkan dalam tata tertib yang telah menjadi komitmen siswa dan petugas tata tertib misalnya siswa terlambat masuk harus membuat surat pernyataan, apabila menaiki sepeda motor pada saat nasuk halaman sekolah mesin tidak 
dimatikan maka dikenakan sanksi untuk menuntun sepeda dengan memutari halaman sekolah, dengan demikian membentuk karakter siswa memiliki semangat kesetaraan

Jiwa kepekaan sosial dipupuk dengan solidaritas pada sesama dengan donor darah dilakukan setiap tiga bulan sekali dilaksanakan di sekolah diikuti oleh para siswa, guru maupun pegawai, animo para siswa, guru, dan karyawan sangat besar mereka sudah rutin mendonorkan darah secara dengan demikian terbentuk karakter siswa menghargai nilai-nilai kemanusiaan dan solidaritas dalam kegiatan donor darah ini diorganisir oleh para siswa ekstrakuler PMR dan bekerjasama dengan PMI kabupaten Malang.

Selain donor darah secara sosial kearifan masyarakat malang yang pluralisme, nilai toleransi, setiap hari raya idul fitri setiap siswa menyumbangkan zakat fitrah yang dikelola oleh para siswa yang tergabung dalam organisasi BDI, zakat fitrah dibagikan pada masyarakat di lingkungan sekolah tanpa memandang agama, ras, asal usul setiap masyarakat tidak mampu dibagikan masing-masing $5 \mathrm{~kg}$. Begitu pula pada saat hari raya Idul Adha siswa para siswa, guru dan staf kariyawan menyumbangkan dana yang biasanya digunakan membeli hewan sapi, kambing untuk hewan korban dan dibagikan ke seluruh masyarakat yang tidak mampu, baik yang muslim maupun yang non muslim khusunya warga sekolah maupun masyarakat disekitar sekolah. Bila ada keluarga siswa yang tinggal satu rumah atau ada warga sekolah yang meninggal pengurus BDI masuk ke kelas-kelas untuk menarik uang duka untuk diserahkan keluarga siswa yang meninggal, kegiatan ini melatih mental siswa untuk jujur dan memiliki semangat kebersamaan. Ekstrakurikuler pramuka setiap tahun memiliki program wira karya dengan pengabdian ke masyarakat misalnya ikut kegiatan pengecatan Kampung Warni di Malang, bakti sosial pada masyarakat sekitar dilakukan setaiap tiga bulan sekali.

Dalam bidang seni dan budaya SMAN 1 Sumberpucung melalui program ekstrakurikuler membuka kegiatan-kegiatan yang menguatkan pendidikan karakter untuk melestarikan kearifan lokal Malang misalnya ekstrakurikuler batik membuat desain batik malangan yang ikut di lombakan di Jawa Timur dan mendapat juara ke-2 provinsi. Dalam Ekstrakulikuler tari diajarkan tari Topeng Malangan, tari Topeng Malangan biasanya dipertunjukan secara kolosal oleh Dewan Ambalan Mercu Buana, Gudep SMAN 1 Sumberpucung pada saat pembukaan tahun ajaran baru.

Tari Topeng Malangan yang mengisahkan cerita panji menggambarkan sosok manusia yang utuh sebagai kesatria yang menjadi panutan contoh ketauladanan dalam kehidupan sehari-hari. Dalam cerita panji terdapat konsep baik buruk, cinta kasih, kejujuran, kebaikan budi dan nilai-nilai sosial (Alfian, 2019), mengajarkan pada siswa untuk memiliki karakter yang ada dalam cerita panji, melestarikan karakter kearifan lokal masyarakat Malang.

JPSI, Vol. 2, No., 2, 2019 
Jajan pasar khas Malang, seperti Gatot, horog-horog, nasi empok, kripik tempe, lekuk, digunakan untuk menu wajib bazar yang setiap kelas wajib ikut pada saat hari ulang tahun sekolah yang diselenggarakan minggu ke tiga bulan Oktober setiap tahun. Basar biasanya dibuka setelah kirab siswa-siswi diharuskan membeli dan menjual makanan khas Malang. Menu-menu wajib yang diambil dari jajanan khas Malang ini untuk menumbuh rasa kecintaan pada kuliner daerah yang menjadi ciri khas masyarakat Malang.dan mengarah pada nilai ekonomis karena makanan khas Malang telah menjadi makanan yang enak dan digemari masyarakat di Nusantara, para siswa biasanya sekolah sambil menjajakkan makanan khas daerah Malang misalnya krupuk "Lekuk" khas kecamatan Kromengan membawa nilai ekonomi di sini siswa diajar untuk mandiri dalam berusaha dan menumbuhkan jiwa kewirausahaan khas orang Malang yang progres .

Nilai progresif dari kearifan lokal masyarakat ditumbuhkan melaui jiwa kreativitas pada siswa dengan lomba adu kreativitas setiap kelas melalui kirab budaya yang diselenggarakan oleh SMAN 1 Sumberpucung diselenggarakan setiap satu tahun sekali pada saat menyosong hari ulang tahun sekolah kegiatan kirab dan lomba karya seni tradisional bertujuan untuk menunjukan kreativitas siswa dalam membuat disain carnival, setiap kelas harus mengeluarkan desainnya dan tiap kelas diberikan tema budaya daerah Malangan. kegiatan kirab ini di lakukan dengan keliling jalan desa yang ada di sekitar lokas sekolah. Dalam kirab ini masyarakat setempat dilibatkan untuk ikut serta dan berperan aktif dalam kegiatan kirab. Setelah melakukan kirab warga setempat dan warga sekolah menikmati basar yang diselenggarakan para siswa, yang di ikuti juga oleh masyarakat sektar.

Dalam rangka pelestarian adat istiadat kearifan kota Malang dalam basar sajikan makanan khas tradisional setempat misalnya nasi empok, gatot, horok-horok, Lekuk, yang merupakan makanan khas Malang. Basar harus diikiuti setiap kelas dan dilombakan. Ada waktu 1 Minggu fakultatif yang ditetapkan oleh sekolah, untuk menggali kreatifitas untuk mewujudkan proses pembelajaran kearifan lokal pada siswa, lomba-lomba yang diadakan diantarannya kirab, basar, menghias nasi tumpeng. Sekolah menyelenggarakan lomba pada akhir tahun di antaranya lomba tari khas Malangan, lomba membuat disain batik khas Malangan, lomba melukis klompen. Semua kegiatan kreativitas ini bertujuan untuk melestarikan kecintaan budaya kesenian lokal yang ke depannya bisa mengarahkan pada nilai ekonomi dan menghasilkan siswa yang produktif dan mandiri. Pada setiap lomba yang diselenggarakan oleh sekolah kelas yang tidak ikut berperan aktif maka dikenakan sangsi denda uang, tujuan dari denda ini adalah untuk menumbuhkan jiwa sportifitas yang menjadi kekhasan kearifan lokal masyarakat Malang.

\section{SIMPULAN}

JPSI, Vol. 2, No., 2, 2019 
Kearifan lokal merupakan bagian dari budaya suatu masyarakat yang tidak dapat dipisahkan dari bahasa masyarakat itu sendiri, diwariskan secara turun-temurun dari generasi ke generasi serta sebagai suatu pengetahuan yang berdasarkan pemahaman terhadap budaya dan keadaan alam suatu tempat. Nilai-nilai kearifan lokal masyarakat Malang yang dapat diterapkan dalam pendidikan karakter di sekolah dalam rangka revolusi mental di antaranya, nilai kejujuran (sportifitas), kemandirian, keteguhan hati, kebersamaan, toleransi, dan kepekaan sosial. Rasa kepekaan sosial dilakukan dengan kegiatan bakti sosial yang di programkan dalam ekstrakurikuler Pramuka setiap tiga bulan ada bakti sosial kebersihan lingkugan dan memberikan bantuan sosial berupa bingkisan sembako pada masyarakat sekitar sekolah yang kurang mampu. Setiap awal tahun pelajaran seluruh siswa di bawah bimbingan wali kelas kerja bakti di lingkungan jalan desa untuk melatih rasa kepedulian pada kebersihan lingkungan hidup dan lingkungan sosial.

Nilai progresif dari kearifan lokal masyarakat ditumbuhkan melalui jiwa kreativitas pada siswa dengan lomba adu kreativitas setiap kelas melalui kirab budaya, bazar untuk menumbuhkan jiwa kewirausahaan dengan kuliner khas Malang, menciptakan karya seni dengan berlatar belakang budaya lokal khas masyarakat Malang akan melestarikan budaya seni di Malang yang arahnya dapat mengarah pada sisi kemandirian ekonomi. Kegiatan ini diselenggarakan di SMAN 1 Sumberpucung setiap satu tahun sekali pada saat menyosong hari ulang tahun sekolah, kegiatan kirab dan lomba karya seni tradisional, kegiatan bakti sosial yang diselenggarakan setiap tiga bulan sekali dengan tujuan mendidik para siswa agar dimana pun berada dapat bermanfaat bagi masyarakat.

\section{DAFTAR PUSTAKA}

Afiqoh, N., Atmaja, H. T., \& Saraswati, U. 2018. Penanaman Nilai Kearifan Lokal dalam Pembelajaran Sejarah Pokok Bahasan Perkembangan Islam di Indonesia Pada Siswa Kelas X IPS di SMA Negeri 1 Pamotan Tahun Ajaran 2017/2018. Indonesian Journal of History Education, 6(1), 42-53.

Alfian, S.Y. 2019. Cerita Panji Dalam Panggung Peradaban. Malang: Beta Aksara

Ahmad, L. K. 2011. Mengembangkan Pendidikan Berbasis Keunggulan Lokal Dalam KTSP. Jakarta: Prestasi Pustakaraya.

Budiprabowo, K. 2017. Kearifan Lokal Malang Raya, Pelangi Sastra Malang Feb 25,2017 https://medium.com/@pelangi_sastra/Malang-dan-kearifan-lokalnya045e85c3aa1Diunduh 11 September 201923.00

Dewantara, K.I. 2017. Filsafat Pancasila Menurut Soekarno. Media Presindo. Yogyakarta 
Komensos RI. 2016. Disain Analisis Rencana Srategis Pelaksanaan Restorasi. Jakarta: Bagian Analisis Rencana Strategis Biro Perencanaan Kemensos RI

Nadlir. 2014. Urgensi Pembelajaran Berbasis Kearifan Lokal; Jurnal Pendidikan Agama Islam. Volume 02 nomor; 02 November 2014

Republik Indonesia. 2013. Undang Undang Dasar 1945 \& Amandemen. Bandung: PT Karsa Mandiri Persada.

Ridwan, N. A. (2007). Landasan Keilmuan Lokal. Jurnal IBDA, 5 (1), 2-3.

Sriwilujeng, D. 2017. Panduan Implementasi Penguatan Pendidikan Karakter. Jakarta: Erlangga Group.

Sutrisno, M. 2011. Disorientasi Budaya Agenda Penyikapannya; Makalah Seminar Nasional Pendidikan Karater Bangsa Dalam Prespektif Lintas Agama: Universitas Negeri Malang.

Triguna, IBG Y. 2011. Membangun Karakter Menjalankan Kebenaran dan Kebaikan. Makalah Seminar Nasional Pendidikan Karater Bangsa Dalam Prespektif Lintas Agama: Universitas Negeri Malang.

Unayah, N., \& Sabarisman, M. (2016). Identifikasi Kearifan Lokal Dalam Pemberdayakan Komunitas Adat Terpencil. Sosio Informa, 2(1).

https://radarmalang.id/saatnya-generasi-muda-cintai-kearifan-lokal; 20 Maret 2018

http://edninaculture.blogspot.com/2017/11/kearifan-lokal-kabupaten-malang.htmlBudaya Makanan Daerah ,Minggu, 12 November 2017

http://edninaculture.blogspot.com/2017/11/kearifan-lokal-kabupaten-malang.html, Minggu, 12 November 2017 